\title{
Determinants of Voluntary Audit of Small and Medium Sized Enterprises: Evidence from Vietnam*
}

\author{
Hanh Hong HA ${ }^{1}$, Anh Huu NGUYEN ${ }^{2}$
}

Received: March 10, 2020 Revised: March 21, 2020 Accepted: April 03, 2020

\begin{abstract}
The paper investigates the factors that affect the demand for a voluntary audit of small and medium-sized enterprises (SMEs) in Vietnam. A structured questionnaire survey of 284 SMEs was employed, preceded by in-depth interviews with auditors and SMEs' managers. The research used logistic regression estimator to address econometric issues and to improve the accuracy of the regression coefficients. The results show that the degree of director's view on voluntary audit, related stakeholder, degree of recommendation, and firm size have a statistically significant positive effect on audit decisions of SMEs while degree of audit fee has a statistically significant negative effect, and degree of subjective norm does not affect. This indicated that SMEs are more likely to have an external audit if they have some typical features: it is becoming larger in terms of size, and the directors consider that the audit has a relative benefit outweighing its cost. The research results suggested that Vietnam Government should make a statutory audit of SMEs' financial statements rather than make it an option for SMEs. The auditing firms were also recommended to actively take their audit services to SMEs rather than waiting for the SMEs' managers to contact them for their services.
\end{abstract}

Keywords: SMEs, Voluntary Audit, Financial Statement Audit, Vietnam

JEL Classification Code: G30, M40, M42

\section{Introduction}

In Vietnam, small and medium-sized enterprises (SMEs) play an important role in socio-economic development. In the case of Vietnam, SMEs have operated in most regions and localities across the country, which helps firms utilize and exploit the local resources (Nguyen \& Phan, 2016). Vietnamese SMEs have some typical characteristics such as

*This research is funded by the National Economics University (NEU), Hanoi, Vietnam. The authors thank anonymous referees for their contributions and the NEU for funding this research.

${ }^{1}$ First Author and Corresponding Author. Lecturer, School of Accounting and Auditing, The National Economics University, Vietnam [Postal Address: 207 Giai Phong Road, Dong Tam Ward, Hai Ba Trung District, Hanoi, 116000, Vietnam]

Email: hahonghanh1@gmail.com

${ }^{2}$ Dean, School of Accounting and Auditing, The National Economics University, Vietnam, Email: anhnh@neu.edu.vn

(c) Copyright: The Author(s)

This is an Open Access article distributed under the terms of the Creative Commons Attribution Non-Commercial License (http://Creativecommons.org/licenses/by-nc/4.0/) which permits unrestricted noncommercial use, distribution, and reproduction in any medium, provided the original work is properly cited. small scale of business, unskilled labor, outdated technology, lack of capital and low productivity (Bui, Nguyen, \& Nguyen, 2018). The Ministry of Planning and Investment has reported that there have been approximately 620,000 SMEs at the date of 31/12/2019. Despite the important role of SMEs in the national economy, it is a voluntary audit appointment for this sector to have their annual accounts audited through the Decree 59 of the Government 2011. The Decree denotes that Vietnamese companies regarded as small and medium-size and private-owned do not need to have their annual financial statements audited by an independent auditor.

In fact, the SMEs in Vietnam are currently dealing with many difficuties: firstly, they are not able to guarantee investors' confidence; secondly, revenue and profit of SMEs tend to decrease, following the increasing rate of enterprises going bankrupt, and, thirdly, the performance of SME is much lower than the figure for the entire sector. In order to resolve this situation, SMEs should implement management control in both financial and non-financial activities. One of the most useful management control is auditing, which is the accumulation and evaluation of evidence about information to determine and report on the degree of correspondence 
between the information and established criteria (Arens, Elder, Beasley, \& Hogan, 2020). SMEs can improve their operations by engaging the services of professional auditors because the professional auditor can assist SMEs operate in a competitive environment to harmonise operational considerations within long-term plans to enhance their survival, especially for SMEs in emerging countries (Chu \& $\mathrm{Ki}, 2019)$.

The fundamental purpose of an audit is to inform shareholders about how the directors managed the company's finances on behalf of them. Hence, the audit plays an important role to help the shareholders as well as stakeholders involved in decision-making process about, for examples, investment, finance or trade with the company. The demand for audit can be explained on two principal theories: agency and stewardship theories. Agency theory addresses the relationship where in a contract the principal engage another person to perform some service that involves delegating some decision-making authority to the agent. The separation of ownership and control leads to information asymmetry that affects the owner's (the principal) ability to effectively monitor if the management (the agent) has acted in their best interests (Jensen \& Meckling, 1976). Stewardship theory additionally documents that management is hired to act in the best interest of the company's owners. Chae, Nakano, and Fujitani (2020) stated that the effect of audit quality is verified. Auditors can mitigate risks by playing a role as corporate governance device mechanism to reduce agency costs. The enhancement of technology and product innovation is positively related to the total factor productivity growth rate that suggests auditors play an important role to control an entity's performance (Lee \& Xuan, 2019).

In order to reduce the information asymmetric as well as to enhance the verifiability of the financial statements prepared by the management, it is necessary for companies to acknowledge the benefit and value of an audit. Kamarudin, Zainal, and Smith (2012) provides evidence that countries such as the United Kingdom, United States, Australia and several countries in Europe have exempted small companies from the annual compulsory audit requirement. For instance, in the USA, there is no statutory audit requirement for companies other than listed companies. In the case of the ASEAN region, other countries have different legislation of audit exemption. Effective from June 2004, Singapore companies with a turnover of less than $\mathrm{S} \$ 5$ million are exempted. On the other hands, Malaysia continues to legally require all companies to be annually audited, with no exemption.

The main motivation for voluntary financial audit among small companies is a result of decision-making process comparing benefit and cost of each company. Their owners manage many small companies in Vietnam where both directors and shareholders are the same person. Therefore, in this case, the fundamental purpose of an audit intended to reduce conflict between manager and shareholder is unnecessary. Removing the need of the audit, the small companies consider other benefits of the audit that are reduce costs and save management time in preparing their annual accounts; reduce major risks; and target future financing plans. On the other hands, the cost of conducting an audit is obviously audit fee, which is relatively high for small companies. During the decision-making process the question raised is what the main factors might affect the motivation for voluntary financial audit decision of SMEs. This paper proposes a theoretical framework to identify these factors influencing the voluntary audit decision of SMEs in Vietnam.

Several studies have been carried out in developed countries such as the United Kingdom, Australia, and Germany, but very few researchers have examined what determines the demand for voluntary audit service among SMEs in emerging countries. Prior studies on this topic do not address in detail the factors influencing the decision of using financial statement audit. The theoretical background also appears to show no evidence to explain the meaning underneath. The purpose of this study is to identify, evaluate and measure the factors affecting voluntary audit of SMEs in Vietnam. The study therefore contributes to the existing literature for a more comprehensive approach to applying some theories to explain the problems. Moreover, this paper finds relevance in fulfilling the research gap and investigates the internal and external factors that could affect ownermanagers of SMEs to use financial statement audit service.

Following the introduction, the paper is structured as follows. Section 2 provides a literature review. Section 3 presents the research hypotheses. Section 4 explains the research methodology. Section 5 presents and discusses results. Section 6 concludes.

\section{Literature Review}

After a long time performing compulsory audit in all economic sectors, many countries gradually ease regulations, and SMEs can voluntarily choose to be audited or not. Allowing a typical group to decide whether to audit financial statements has led to much debate in academic circles, regulators, policy makers and professional bodies.

The first and major reason why some small companies continue to be audited is to help control the conflict of interest between managers, shareholders and external users (Tauringana \& Clarke, 2000). Agency theory (Jensen \& Meckling, 1976) suggests that the directors will be willing to bear the cost of the audit to support agency relationships with principals (the owners) where there is information asymmetry. In small (non-family) companies the principal is anyone who is distant from the actions of management and is unable to verify them, for instance, the external shareholders, lenders and creditors. Audit provides the external users of financial 
statements reasonable assurance that the reports are prepared in compliance with accounting standards and ensure the credibility of its information. An analysis of the 1999 survey conducted by Collis (2012) provided evidence of several factor influencing the demand for a voluntary audit. The result found that turnover could represent the size of company, but that size is not important as the directors' perceptions of the value of audit in terms of improving the quality of information and providing a check on internal records. Agency relationships in this case with (non-family) owners and external users (lenders, creditors) were also significant influences on the demand for the audit. The survey also reported that the director's educational profile was an influential factor.

In the context of developing countries, Dnishev and Alzhanova (2016) identified the significant role of agency conflict between a manager and shareholders in the determination of company size. Findings show that the bigger the size of a company, the more conflict there is between its managers and shareholders. In Vietnam, many small companies are managed by their owners. Therefore, in this case when the small company expands its scale, it may lead to exposure to high risks, for instance, company's inherent risks (the likelihood of a material misstatement arising) and control risk (the likelihood of the accounting control detecting any material misstatement). The ownermanager may want an independent check on internal controls to reduce the chance of material errors. Collis (2012), a survey commissioned by the UK Department of Trade and Industry (DTI) found that 50 percent of respondents considered that audit helped to protect against fraud and as the size of the company grew, they would consider conducting a voluntary audit. The audit process also includes checks to identify the existence of fraud and to assess the adequacy of the company's internal control (Davis, Bagozzi, \& Warshaw, 1989; Zerni, Haapamäki, Järvinen, \& Niemi, 2012) conducted a research in public and private companies showing that they are aware of the benefits that the audit gives the enterprises such as improve credit rating, reduce risks, and attract external investors.

Many viewpoints have appeared as to whether SMEs should or should not be subject to an annual mandatory audit. Rahman, Reah and Chaudhory (2019) stated that Big4 audit firms have better audit quality than others and mostly depend on their reputation and size. However, evaluating the quality of an audit is the most controversial issues because the audits do not disclose information and its quality cannot be directly observed by financial statement users (Tran, Khairi, \& Laili, 2019). Nguyen and Tran (2017) stated that three factors include auditee size, Big 4 audit firms, and auditee complexity measured by the number of subsidiaries, branches, associates, affiliates and joint ventures; these have a statistically significant positive effect on the audit fee for companies in Vietnam. Audit fee is one of the main reasons for eliminating the mandatory audit. There have been big debates among regulators as well as academics on the issues. In the academic literature we can identify two main approaches to explaining the reason for choosing financial audit services.

The first approach focuses on the reduction of information risk that accrues, as an audit leads to more reliable reporting. Firms with fewer information and higher agency costs tend to choose a financial statement audit to strengthen their internal control and thereby alleviate potential agency conflicts (Watts \& Zimmerman, 1983; Chow, 1982; Abdelkhalik, 1993; Blackwell, Noland, \& Winters, 1998); Carey, Sumnett, \& Tanewski, 2000; Hay \& Davis, 2000; Tauringana $\&$ Clarke, 2000). The second approach such as the research of Rennie, Senkow, Rennie, and Wong (2003), Marosi and Masoud (2004). Collis (2012), Norashikin, Zubaidah, and Smith (2012), Othman, Abidin, and Thirumanickam (2013) states that if the owners/managers perceived the benefit of having accounts audited they will go for a voluntary financial audit. In this research, we attempt to synthesize the two approaches by developing a model of determinants of voluntary audits among SMEs, which represents variables proxying for both agency conflict and owners/ directors' view on voluntarily financial audits.

\section{Research Hypotheses}

The analysis of the literature draws on some of the key findings and tests six hypotheses. The variables in the study will be explained as following:

Voluntary Financial Audit is the dependent variable in the analysis and consists of two groups. The first group includes companies where the directors would have the accounts audited on a voluntary basis even if the company was not legally required to do so. The second group includes companies where the directors would not have the accounts audited if the company were free to choose. Non-responses are excluded. Directors' View on Financial Audit represents factor that capture whether the directors perceive the benefit of an audit as providing a check on accounting records and systems, improving the quality or the credibility of the financial information and having a positive effect on the company's credit rating score respectively.

H1: The likelihood of directors choosing a voluntary audit increase with perceptions that the benefits outweigh the costs of having an audit.

Related Stakeholder represents agency relationships with shareholders and captures whether the company is wholly family-owned. This factor also represents agency relationships with shareholders and captures whether there are external shareholders. The external stakeholders such as bank or other providers of finance have a strongly impact on the statutory accounts. It is a dummy variable and is used to test $\mathrm{H} 2$. 
H2: The likelihood of directors choosing a voluntary audit increase with perceptions that many related stakeholders affect them.

Subjective Norm and Recommendations represent the factors in accordance of TRA. Subjective norm captures the attitude gives the director's opinion about whether the action is positive or negative.

H3: The likelihood of directors choosing a voluntary audit increase with perceptions that their subjective norm encourages them to do so.

Recommendation describes the social effect on directors' decision.

H4: The likelihood of directors choosing a voluntary audit increase with enticement from social impact.

Size represents size factors in the analysis and captures total assets/equity on the balance sheet.

H5: The likelihood of the directors choosing a voluntary audit increases with size, as measured by total assets/equity.

Audit Fee represents factors relating to the cost a director needs to take into account for decision. It is the total cost that a company has when using auditing services. Audit service fees will be based on a competition among auditing firms. Directors will weigh the costs and benefits received when using the service. If directors are aware that the cost of money is not significant or worthy of receiving the benefits, they are willing to use the service.

H6: The likelihood of the directors choosing a voluntary audit does not increase with the audit fee.

\section{Data and Methodology}

\subsection{Data Collection}

In constructing the final sample, the data collection has to fulfill a number of requirements based on original data from Vietnam General Statistic Office of the year ending 2019.

Firstly, the companies for whom account audited is not compulsory under Vietnamese law. Therefore, some types of firms iare excluded such as state-owned enterprises, FDI (Foreign Direct Investment) firm and others. The list is screened to remove dormant companies, subsidiaries, groups and holding companies in order to retain only active independent companies, where financial reporting decisions would not be influenced by group policies. As a proxy for qualifying as a medium-sized company at the time of the study, selection was made on the basis of the company meeting the following criteria in their 2019 accounts. For sectors of agriculture, forestry and fisheries, industry and construction: balance sheet total from VND20 billion to
VND100 billion; number of employees from 200 to 300 . For sectors of trade and services: balance sheet total from VND10 billion to VND50 billion; number of employees from 50 to 100 .

Secondly, big companies in term of size requirement (total assets on balance sheet and total employees) have been excluded from the sampling frame, leaving 30,115 companies. To qualify to be an medium-sized company, total assets/ equities on balance sheet must range from VND20 billion to VND100 billion for two industry groups, Agriculture, forestry and fisheries, and Industry and construction; and VND10 billion to VND50 billion for the service industry. This resulted in a list of 3,202 companies that represented the population of companies. Because of limitation scope of the analysis in Hanoi, 600 questionnaires have been sent via post and email. The questionnaire was developed by conducting in depth interviews. In order to increase the response rate, a reminder has been sent with enclosing another copy of the questionnaire and prepaid envelope. A further group of companies was eliminated from the initial list because information received indicated they had ceased trading, moved away or because the owner was absent or unable to participate. This reduced the list to 473 companies. This size of the sample is partly sufficient to be representative. Out of 473 companies, only 284 responded, representing a $60 \%$ response rate.

\subsection{Research Methodology}

Qualitative research is used in the factor exploration stage, document review, and in-depth interview to get opinion from experts. The purpose of this study aimed to collect opinions, and discover what other factors impact on deciding the audit service. The questionnaire was developed by conducting three interviews with four independent auditors of medium company client and four directors of medium companies. The questionnaire was then reviewed by a number of researchers and was being sent via post and email for preliminary quantitative research. The description of variables as follows:

VOLAUDIT (dependent variable): Whether the company would have a voluntary audit (Yes/ No).

DIRECVIEW: Extent of agreement about the benefit of having an audit.

RELSTAHOLDER: Whether the company has related stakeholders.

SUBNORM: Extent of agreement that the subjective norm affect the decision of having an audit.

RECOM: Extent of agreement that the recommendations affect the decision of having an audit.

SIZE: Total assets/equity on Balance Sheet

AUDFEE: Extent of agreement that the audit fee affect the decision of having an audit. 
The preliminary test was used to determine the independence of the two groups in the dependent variable (VOLAUDIT) and each independent variable measured on a non-parametric ratio scale (SIZE) or ordinal scale (DIRECVIEW, SUBNORM, RECOM and AUDFEE), Mann-Whitney tests of difference were conducted. Applying a small sample of 17 SMEs for comparing two small sets of observations as a following (see Table 1):

The low value of the probability statistics in the table provide evidence of a significant difference between two groups in each test $(p \leq 0.05)$ and therefore these independent variables are included in the regression model. Chi-square tests were used to measure the association between the two groups in the independent variable (VOLAUDIT) and each of the independent variables measured on a dichotomous nominal scale (RELSTAHOLDER).

The probability statistic in Table 2 provides evidence of a significant positive association between the two groups in the dependent variable (VOLAUDIT) and the category in the independent variable (RELSTAHOLDER) $(p \leq 0.005)$. Therefore the independent variable can also be included in the regression model. The objective of preliminary quantitative research is also to evaluate the reliability of the scale was built and eliminate the observed variations are not consistent with the research model through Cronbach Alpha coefficient. The scale coefficient equals 0.6 or higher is acceptable.

Table 3 presents the results of reliability analysis of the scale. The result of Cronbach's Alpha of DIRECVIEW equals 0.902 and the total correlation is greater than 0.3 illustrating that the measurement scale is acceptable. The result of Cronbach's Alpha of RELSTAHOLDER equals 0.675 and the total correlation is greater than 0.3 illustrating that the measurement scale is acceptable. The result of Cronbach's Alpha of SUBNORM equals 0.695 and the total correlation is greater than 0.3 . However, the total correlation of item SUBNORM3 equals 0.19, thus, is smaller than 0.3, meaning that, if we eliminate the item, Cronbach Alpha of the model will be higher. The item SUBNORM3 is therefore eliminated from the model. The result of Cronbach's Alpha of RECOM equals 0.881 and the total correlation is greater than 0.3 , illustrating that the measurement scale is acceptable. The result of Cronbach's Alpha of RELSTAHOLDER equals 0.675 and the total correlation is greater than 0.3 , illustrating that the measurement scale is acceptable. The result of Cronbach's Alpha of AUDFEE equals 0.764 and the total correlation is greater than 0.3 . However, the total

Table 1: Mann-Whitney tests (non-parametric ratio and ordinal variables)

\begin{tabular}{|c|c|c|c|c|c|c|c|c|}
\hline Variable & VOLAUDIT & $\mathbf{N}$ & Mean rank & $\begin{array}{l}\text { Sum of } \\
\text { ranks }\end{array}$ & $\begin{array}{c}\text { Mann- } \\
\text { Whitney U }\end{array}$ & $\begin{array}{l}\text { Wilcoxon } \\
\text { W }\end{array}$ & $\mathbf{Z}$ & $\mathbf{P}$ \\
\hline SIZE & $\begin{array}{l}0 \text { No } \\
1 \text { Yes } \\
\text { Total }\end{array}$ & $\begin{array}{r}11 \\
6 \\
17 \\
\end{array}$ & $\begin{array}{l}4.71 \\
9.00\end{array}$ & $\begin{array}{l}33.00 \\
45.00\end{array}$ & 40.00 & 33.000 & -10.731 & .000 \\
\hline DIRECVIEW & $\begin{array}{l}0 \text { No } \\
1 \text { Yes } \\
\text { Total }\end{array}$ & $\begin{array}{r}14 \\
3 \\
17\end{array}$ & $\begin{array}{l}5.36 \\
8.12\end{array}$ & $\begin{array}{l}45.00 \\
53.00\end{array}$ & 47.00 & 45.00 & -8.519 & .000 \\
\hline SUBNORM & $\begin{array}{l}0 \text { No } \\
1 \text { Yes } \\
\text { Total }\end{array}$ & $\begin{array}{r}7 \\
10 \\
17\end{array}$ & $\begin{array}{l}3.22 \\
2.18\end{array}$ & $\begin{array}{l}64.00 \\
57.00\end{array}$ & 58.00 & 64.00 & -9.864 & .000 \\
\hline RECOM & $\begin{array}{l}0 \text { No } \\
1 \text { Yes } \\
\text { Total }\end{array}$ & $\begin{array}{r}14 \\
3 \\
17\end{array}$ & $\begin{array}{l}6.23 \\
7.13\end{array}$ & $\begin{array}{l}78.00 \\
94.00\end{array}$ & 87.00 & 78.00 & -8.851 & .000 \\
\hline AUDFEE & $\begin{array}{l}0 \text { No } \\
1 \text { Yes } \\
\text { Total }\end{array}$ & $\begin{array}{r}15 \\
2 \\
17\end{array}$ & $\begin{array}{l}7.01 \\
8.53\end{array}$ & $\begin{array}{l}83.00 \\
91.00\end{array}$ & 89.00 & 83.00 & -8.928 & .000 \\
\hline
\end{tabular}

Table 2: Chi-square tests (nominal variables)

\begin{tabular}{|c|c|c|c|c|c|c|c|}
\hline Variable & \multicolumn{3}{|c|}{ VOLAUDIT } & N & Chi-square & df & p \\
\hline \multirow{3}{*}{ RELSTAHOLDER } & & 0 No & 1 Yes & & & \\
& 0 No & 6 & 4 & 10 & 33.103 & 1 \\
& 1 Yes & 5 & 2 & 7 & & .000 \\
& Total & 11 & 6 & 17 & & \\
\hline
\end{tabular}


Table 3: Reliability analysis of the scale

\begin{tabular}{|c|c|c|c|c|}
\hline Items & $\begin{array}{c}\text { Scale mean if item } \\
\text { deleted }\end{array}$ & $\begin{array}{c}\text { Scale variance if } \\
\text { item deleted }\end{array}$ & $\begin{array}{c}\text { Corrected item - total } \\
\text { correlation }\end{array}$ & $\begin{array}{c}\text { Cronbach's Alpha if } \\
\text { item deleted }\end{array}$ \\
\hline \multicolumn{5}{|c|}{ Directors' view on the financial audit - DIRECVIEW: Cronbach Alpha = 0.902} \\
\hline DIRECVIEW1 & 24.50 & 10.32 & .56 & .78 \\
\hline DIRECVIEW2 & 24.59 & 11.47 & .79 & .88 \\
\hline DIRECVIEW3 & 24.98 & 11.79 & .72 & .89 \\
\hline DIRECVIEW4 & 24.45 & 12.54 & .61 & .90 \\
\hline DIRECVIEW5 & 24.77 & 12.67 & .77 & .91 \\
\hline DIRECVIEW6 & 24.14 & 11.22 & .84 & .81 \\
\hline DIRECVIEW7 & 24.72 & 11.34 & .53 & .81 \\
\hline DIRECVIEW8 & 24.34 & 11.75 & .75 & .80 \\
\hline \multicolumn{5}{|c|}{ The effects of related stakeholders - RELSTAHOLDER: Cronbach Alpha $=0.675$} \\
\hline RELSTAHOLDER 1 & 11.48 & 2.17 & .43 & .65 \\
\hline RELSTAHOLDER 2 & 11.52 & 2.57 & .51 & .42 \\
\hline RELSTAHOLDER 3 & 11.37 & 2.32 & .63 & .56 \\
\hline \multicolumn{5}{|c|}{ Subjective Norms - SUBNORM: Cronbach Alpha = 0.695} \\
\hline SUBNORM 1 & 14.01 & 5.25 & .48 & .67 \\
\hline SUBNORM 2 & 13.45 & 5.43 & .45 & .56 \\
\hline SUBNORM 3 & 13.45 & 4.77 & .19 & .78 \\
\hline SUBNORM 4 & 13.87 & 5.37 & .50 & .62 \\
\hline SUBNORM 5 & 13.76 & 5.51 & .51 & .42 \\
\hline \multicolumn{5}{|c|}{ Recommendations - RECOM: Cronbach Alpha = 0.881} \\
\hline RECOM 1 & 11.12 & 22.54 & 67 & .87 \\
\hline RECOM 2 & 11.76 & 21.75 & .65 & .81 \\
\hline RECOM 3 & 11.90 & 21.45 & .59 & .78 \\
\hline RECOM 4 & 11.94 & 23.30 & .54 & .85 \\
\hline RECOM 5 & 11.29 & 20.58 & 61 & .76 \\
\hline \multicolumn{5}{|c|}{ Audit Fee - AUDFEE: Cronbach Alpha = 0.764} \\
\hline AUDFEE 1 & 14.62 & 5.78 & .43 & .67 \\
\hline AUDFEE 2 & 14.31 & 4.99 & .07 & .82 \\
\hline AUDFEE 3 & 14.71 & 5.01 & .49 & .70 \\
\hline AUDFEE 4 & 13.75 & 5.12 & .67 & .69 \\
\hline
\end{tabular}

correlation of item AUDFEE2 equals 0.07 is smaller than 0.3 , meaning that if, we eliminate the item, the Cronbach's Alpha of the model will be higher. The item AUDFEE2 is therefore eliminated from the model. After checking the reliability of the scale and eliminating the observed variables not eligible, the scale is encoded again in preparation for formal quantitative research at a larger scale.

The logistic regression model tests the hypotheses $\mathrm{H} 1$ to H6. The model is presented as following:
VOLAUDIT $=\beta_{0}+\beta_{1}$ DIRECVIEW + $\beta_{2}$ RELSTAHOLDER $+\beta_{3}$ SUBNORM $+\beta_{4}$ RECOM + $\beta_{5} \mathrm{SIZE}+\beta_{6} \mathrm{AUDFEE}+\varepsilon_{\mathrm{i}}$

Where:

VOLAUDIT: Voluntary audit

DIRECVIEW: Director's view on voluntary audit RELASTAHOLDER: Related stakeholder dummy SUBNORM: Subjective norm on voluntary audit RECOM: Degree of recommendation on voluntary audit 
SIZE: Natural logarithm of total assets

AUDFEE: Degree of audit fee on voluntary audit

\section{Results and Discussion}

\subsection{Results of Analysis on Audit Decision}

In order to test a company's decision to have its accounts audited, statistic were collected from 284 surveyed companies and shows that 165 companies (58\%) had filed unaudited accounts, compared to 119 companies (42\%) that had filed audited accounts. In order to ascertain the factors affecting the decision to file unaudited accounts, the directors were asked to express various reasons in their own words, rather than prompting them with a list of suggested answer.

Of the 119 companies that stated that they had their accounts audited in 2019, there are several reasons influencing the audit decision as the continuation of an established company policy, the owner-manager's desire to do so. The accountant's advice is an important influence. From the opinions collected during the in-depth interview

Table 4: Reasons for having a voluntary audit

\begin{tabular}{|l|c|c|}
\hline Reason & $\begin{array}{c}\text { Number of } \\
\text { companies }\end{array}$ & $\begin{array}{c}\% \text { of } \\
\text { companies }\end{array}$ \\
\hline Check/assurance for & 83 & 70 \\
third parties & 17 & 14 \\
Good practice/ & 19 & 16 \\
governance & 119 & 100 \\
Other & & \\
Total & & \\
\hline
\end{tabular}

Table 5: Reasons for not having a voluntary audit

\begin{tabular}{|l|c|c|}
\hline \multicolumn{1}{|c|}{ Reason } & $\begin{array}{c}\text { Number of } \\
\text { companies }\end{array}$ & $\begin{array}{c}\text { \% of } \\
\text { companies }\end{array}$ \\
\hline No benefit/not & 52 & 44 \\
necessary & 49 & 42 \\
Cost savings & 16 & 14 \\
Other & 117 & 100 \\
Total & & \\
\hline
\end{tabular}

with auditors and directors, the accountant's advice is likely to be particularly valuable for medium-sized companies. Interestingly, even though these companies had incurred the cost of having their accounts audited, they considered lower accountancy fees were an important factor. This implies that they may be willing to bear the financial cost of audit as it means lower costs elsewhere, for example, lower borrowing costs.

Table 4 summarises the result of categorizing these answers and shows that the main reason for wanting a voluntary audit is the independent check and the associated assurance this provides to third parties. The main benefit of having the accounts audited in connection with agency relationships, and a secondary benefit that relates to good management.

Of the 165 companies that stated that they would not be willing to perform an audit, 117 provided responses. Table 5 presents the result of categorizing these answers and reveals that the main reasons for dispensing with the audit relate to lack of need and potential cost savings. The reasons are shown in the Table 4 and 5 for the audit decision provide further evidence of directors's need to balance the cost of the audit against the benefit.

\subsection{Results of Factors Affecting Medium Sized Enterprises' Voluntary Audit Decision}

Table 6 presents the correlation matrix for the model variables. A positive (negative) correlation here implies that an increase (decrease) in a given variable leads to the firm choosing a voluntary audit. A Spearman (Pearson) correlation was computed to assess the association between the dependent and independent variables, with Spearman (Pearson) correlation coefficients above the diagonal line. The Spearman (Pearson) correlation is a nonparametric test, which measures the strength and direction of association between two variables that are measured on an ordinal or continuous scale, and its associated correlation coefficients are denoted below by the symbol $r_{s}$. It is a useful test for cases when a Pearson correlation cannot be computed due,

Table 6: Correlation matrix for the model variable

\begin{tabular}{|l|c|c|c|c|c|c|c|}
\hline \multicolumn{1}{|c|}{ Variables } & VOLAUDIT & DIRECVIEW & RELSTAHOLDER & SUBNORM & RECOM & SIZE & AUDFEE \\
\hline VOLAUDIT & 1.00 & 0.421 & 0.387 & -0.051 & 0.626 & 0.309 & -0.402 \\
\hline DIRECVIEW & 0.421 & 1.00 & 0.025 & 0.003 & 0.050 & 0.00 & -0.017 \\
\hline RELSTAHOLDER & 0.387 & 0.025 & 1.00 & 0.058 & 0.046 & -0.206 & -0.079 \\
\hline SUBNORM & -0.051 & 0.003 & 0.108 & 1.00 & -0.048 & 0.207 & 0.009 \\
\hline RECOM & 0.626 & 0.050 & 0.046 & -0.048 & 1.00 & 2.280 & -0.039 \\
\hline SIZE & 0.309 & 0.00 & -0.206 & 0.207 & 2.280 & 1.00 & 0.021 \\
\hline AUDFEE & -0.402 & -0.017 & -0.079 & 0.009 & -0.039 & 0.021 & 1.00 \\
\hline
\end{tabular}


for example, to discrete variables being used shows that there is a weak positive correlation.

The Spearman correlation shows that there is a moderate positive correlation between voluntary audit decision (VOLAUDIT) and DIRECVIEW $\left(\mathrm{r}_{\mathrm{s}}=0.421, \mathrm{p}=0.000\right)$, RELSTAHOLDER $\left(\mathrm{r}_{\mathrm{s}}=0.387, \mathrm{p}=0.000\right)$ and SIZE $\left(\mathrm{r}_{\mathrm{s}}=\right.$ $0.309, \mathrm{p}=0.000)$. It has also found that there is very weak negative correlation between SUBNOM and VOLAUDIT. The strongest positive correlation is expressed between RECOM and VOLAUDIT $\left(r_{s}=0.626, p=0.000\right)$ which may be explained that medium sized companies mostly be affected by recommendation to make voluntary audit decision.

Table 7 categorises the variables in the analysis by type of data, coding, number of companies providing data $(\mathrm{N})$ and descriptive statistics as appropriate.

Table 8 presents the results of a logistic regression model of the likelihood that medium-sized companies engage an audit. The model includes observations for the year 2019 . The pseudo $\mathrm{R}^{2}$ shown in the notes to the table indicates that the independent variables in the regression model explain
$74 \%$ of the demand for the audit. The higher values of the Wald statistic and the lower value of the probability statistic of SIZE, DIRECVIEW, AUDFEE in comparison to other variables indicates that the size of a company (in term of total assets/ equities on balance sheet), the view of director with perceptions that the audit would improve the quality of the information and the existence of audit fee as cost-burden are the most influential.

The table shows that the probability statistic for SUBNORM is non-significant $(\mathrm{p}>0.05)$. This provides evidences to reject $\mathrm{H} 3$, as it means that the audit decision is not significantly influenced by the view that directors choosing a voluntary audit increase with perceptions that their subjective norm encourage them to do so. However, the results for DIRECVIEW, SIZE, RECOM and RELSTAHOLDER are significant $(\mathrm{p} \leq 0.05)$. Moreover, in the other hand, the factor coefficient $(\beta)$ for AUDFEE indicates the expected negative relationship with the demand for a voluntary audit which is explained that the less audit fee is the more demand for a voluntary audit.

Table 7: Descriptive statistics

\begin{tabular}{|l|c|c|c|c|}
\hline \multicolumn{1}{|c|}{ Variable } & Min & Max & Mean & Standard deviation \\
\hline VOLAUDIT & 0 & 1 & N/A & N/A \\
\hline SIZE & 7.13 & 12.54 & 9.678 & 0.93 \\
\hline DIRECVIEW & 1 & 5 & 4.05 & 1.19 \\
\hline SUBNORM & 1 & 5 & 3.35 & 1.38 \\
\hline RECOM & 1 & 5 & 3.95 & 1.18 \\
\hline AUDFEE & 1 & 5 & 3.55 & 1.29 \\
\hline RELSTAHOLDER & 0 & 1 & $\mathrm{~N} / \mathrm{A}$ & $\mathrm{N} / \mathrm{A}$ \\
\hline
\end{tabular}

Table 8: Demand for a voluntary audit: logistic regression

\begin{tabular}{|c|c|c|c|c|c|c|}
\hline \multirow[t]{2}{*}{ Regression Statistic } & Multiple R & R Square & \multicolumn{2}{|c|}{ Adjusted R Square } & Standard Error & Dublin-Watson \\
\hline & 0.86242 & 0.74376 & \multicolumn{2}{|c|}{0.71054} & 20.68263 & 1.729 \\
\hline ANOVA & Df & SS & \multicolumn{2}{|c|}{ MS } & $\mathbf{F}$ & Sig.F \\
\hline Regression & 30 & 67048.746 & \multicolumn{2}{|c|}{9578.392} & 22.391 & 0.000 \\
\hline Residual & 59 & 5796.4097 & \multicolumn{2}{|c|}{98.2442} & & \\
\hline Total & 63 & 110685.938 & \multirow[b]{2}{*}{ Wald } & & \multirow[b]{2}{*}{$\mathbf{P}$} & \multirow[b]{2}{*}{$\operatorname{Exp}(\beta)$} \\
\hline Variable & $\beta$ & SE & & df & & \\
\hline SIZE & .001 & .000 & 22.970 & 1 & .000 & 1.001 \\
\hline DIRECVIEW & .393 & .103 & 14.664 & 1 & .000 & 1.482 \\
\hline SUBNORM & .137 & .127 & 1.170 & 1 & .279 & 1.147 \\
\hline RECOM & .245 & .096 & 6.486 & 1 & .011 & 1.277 \\
\hline AUDFEE & .445 & .216 & 4.235 & 1 & .040 & 1.560 \\
\hline RELSTAHOLDER & -.789 & .212 & 13.777 & 1 & .000 & .455 \\
\hline Constant & -4.176 & .550 & 57.758 & 1 & .000 & .015 \\
\hline
\end{tabular}


Based on the result of the model, some specifications reveal that the directors are more likely to have a voluntary audit if the company has the following characteristics: it is larger in terms of total assets (size), and the directors consider the audit, improving the quality of the financial information, has a positive effect on credit rating score and provides a check on accounting records and systems. With regard to the organizational complexity and risk factors, the size coefficient is positive and significant at the $\mathrm{p}$ value 0.5 percent level. This finding may be explained by the argument that the agency costs increase with company size, as the monitoring function is "inherently more difficult and expensive in a larger organization" (Jensen \& Meckling, 1976). Further it is argued that there is more wealth at risk in larger companies, which increases agency costs. Thus, larger firms are more likely to appoint an external auditor.

The company is not wholly family-owned (for example, there are non-family shareholders) and has shareholders without access to internal information. This indication might be explained by the conflict that appears between the agency and the principal (agency theory). The company is also affected by the external stakeholders, such as the bank or other providers of finance if the directors normally give a copy of the statutory accounts to them. Recommendation is considered to be a strong factor as medium-sized enterprises are willing to have accounts audited if they have some suggestion from professional accountants. In some cases, the directors have acknowledged the benefit of an audit. However, they have found it is difficult to explore some audit service information. The auditing firms therefore are recommended to take their audit services to SMEs rather than waiting for the firms' owner-managers to voluntarily contact them for their services.

\subsection{Discussion and Recommendations}

Firstly, the findings of this study can be generalized to other active, independent and private limited companies of small size. They should be of interest to accountants and the accountancy profession, auditors and auditing firms, those who advise medium-sized companies, regulators and ownermanagers, who are the four major players in the financial reporting context of medium-sized companies. The results suggest that, when a competent and reliable external auditor is used to support the accounting function and assist in the checking of prepared financial statements, the overall financial reporting and auditing process seems to provide more value to the owner-manager. This is consistent with the idea that the auditor plays a key role in providing advice as well as other assurance services, as he or she develops a critical mass of knowledge about the company, which supports internal decision-making based on audited information. This finding is in agreement with Barrar, Wood, Jones, and Vedovato
(2002), who suggest that outsourcing professional services provides an efficient solution in a company performance when it comes to medium-sized company.

Secondly, based on the theoretical framework of this study, the Government should consider defining a small and medium-sized company in Vietnam. There, SMEs are businesses fully registered in accordance to Vietnamese law and categorized into two levels based on total assets/equity and number of employees. The findings of this study provide evidences that the size based on total assets is not a sufficient measure on its own for capturing the costs and benefits of the audit. There are other qualitative factors. For examples, in the case of the UK, the definition of SME has been amended based on the turnover; policy-makers should be aware that the new category of SMEs would contain two subgroups with differing needs. This is demonstrated by the significant proportion of directors, whose audit decisions indicate that the benefits outweigh the costs. The Government also needs of put more effort to encourage companies to choose to have their accounts audited. The findings suggest that the regulator might consider the introduction of a mandatory financial auditing threshold for smaller non-listed firms in recognition of this.

Finally, previous studies suggest that many small and medium-sized companies use the services of an external auditing firm (Collis \& Jarvis, 2002; Blackburn \& Jarvis, 2010), who is often one of the main sources of advice. The results provide consistent evidence of a positive relationship between the owner-manager's perception of the competence and reliability of the services provided by the external accountants and the perceived benefits such as improved internal decision-making, overall benefits from the auditor's services, assurance for the users of the financial information, internal control benefits, advice on changes in accounting and regulations, technical accounting advice, and tax advice.

\section{Conclusion}

The research intended to investigate the determinants of demand for voluntarily financial audit of SMEs in Vietnam. Currently, Vietnam has no compulsory requirement that compels SMEs to have their accounts audited. The study aims to find evidence as well as apply logistic regression model to test the effect of each determinant, which has been built on the literature review. Based on the findings, it is recommended that owners-managers of SMEs should properly recognize the importance of financial audit to their operations. The government should make statutory audit or legal requirement of SMEs' financial statements rather than make it optional. From a macroeconomic viewpoint, this action can be a solution to improve the companies' performance, especially in the context of emerging economy conditions; Vietnam needs a stronger law protection for SMEs. 


\section{References}

Abdel-khalik, A. R. (1993). Why do private companies demand auditing? A case for organizational loss of control, auditing. Journal of Accounting, Auditing and Finance, 8(1), 31-52.

Arens, A. A., Elder, R. J., Beasley, M. S., \& Hogan, C. E. (2020). Auditing and assurance services: an integrated approach $\left(17^{\text {th }}\right.$ ed.). Upper Saddle River, NJ: Pearson Prentice Hall.

Barrar, P., Wood, D., Jones, J., \& Vedovato, M. (2002). The efficiency of accounting service provision. Business Process Management Journal, 8(3), 195-217.

Blackwell, D. W., Noland, T. R., \& Winters, D. B. (1998). The value of auditor assurance: evidence from loan pricing. Journal of Accounting Research, 36(1), 57-70.

Blackburn, R., \& Jarvis, R. (2010). The role of small and medium practices in providing business support to small- and mediumsized enterprises. Retrieved August 1, 2019, from https://www.researchgate.net/publication/43153305

Bui, A. T., Nguyen, M. T. T., \& Nguyen, M. H. (2018). Informal institutions and entrepreneurial orientation: an exploratory investigation into Vietnamese small and medium enterprises. Journal of Economics and Development, 20(2), 107-124.

Carey, P., Sunnett, R., \& Tanewski, G. (2000). Voluntary demand for internal and external auditing by family businesses. Journal of Practice and Theory, 19 (Supplement), 37-51.

Chae, S. J., Nakano, M., \& Fujitani, R. (2020). Financial reporting opacity, audit quality and crash risk: evidence from Japan. Journal of Asian Finance, Economics and Business, 7(1), 9-17. https://doi.org/10.13106/jafeb.2020.vol7.no1.9

Chow, C. W. (1982). The demand for external auditing: size, debt and ownership influences. The accounting Review, 57(2), 272291.

Chu, J., \& Ki, E. S. (2019). Do auditor's efforts of interim review curb the analyst forecast's walkdown? Journal of Asian Finance, Economics and Business, 6(2), 45-54. https://doi. org/10.13106/jafeb.2019.vol6.no2.45

Collis, J. (2012). Determinants of voluntary audit and voluntary full accounts in micro and non-micro small companies in the UK. Accounting and Business Research, 42(4), 1-29.

Collis, J., \& Jarvis, R. (2002). Financial information and the management of small private companies. Journal of Small Business and Enterprise Development, 9(2), 100-110.

Davis, F. D., Bagozzi, R. P., \& Warshaw, P. (1989). User acceptance of computer technology: a comparison of two theoretical models. Management Science, 35(8), 982-1003.

Dnishev, F., \& Alzhanova, F. (2016). Globalization of technological development and opportunities for national innovation systems of developing countries. Journal of Asian Finance, Economics and Business, 3(4), 67-79. https:// doi.org/10.13106/jafeb.2016.vol3.no4.67
Jensen, M. C., \& Meckling, W. H. (1976). Theory of the firm: managerial behavior, agency costs and ownership structure. Journal of Financial Economics, 3(4), 305-360.

Hay, D., \& Davis, D. (2004). The voluntary choice of an audit of any level of quality. Auditing: A journal of Practice and Theory, 23(2), 37-53.

Kamarudin, N., Zainal, A., \& Smith, M. (2012). Audit exemption among SMEs in Malaysia. Asian Review of Accounting, 20(2), 152-162.

Lee, J. W., \& Xuan, Y. (2019). Effects of technology and innovation management and total factor productivity on the economic growth of China. Journal of Asian Finance, Economics and Business, 6(2), 63-73. https://doi.org/10.13106/jafeb.2019. vol6.no2.63

Marosi, A., \& Masoud, N. (2004). Why do firm go dark. Journal of Financial and Quantitative Analysis, 42(2), 421-442.

Nguyen, L. T., \& Phan, M. H. (2016). Liabilities and the impacts on financial performance of the Vietnamese listed small and medium-sized enterprises. Journal of Economics and Development, 18(3), 41-63.

Nguyen, H. P. T., \& Tran, M. H. L. (2017). The determinants of audit fees for companies in Vietnam. Journal of Economics and Development, 19(2), 68-88.

Norashikin, K., Zubaidah, Z., \& Smith, M. A. (2012). Audit exemption among SMEs in Malaysia. Asian Review of Accounting, 20(2), 152-162.

Othman, R., Abidin, Z. Z., \& Thirumanickam, N. (2013). Directors? View on exemption from statutory audit. Asian Journal of Empirical Research, 3(10), 1277-1290.

Rahman, M. M., Meah, M. R., \& Chaudhory, N. U. (2019). The impact of audit characteristics on firm performance: an empirical study from an emerging economy. Journal of Asian Finance, Economics and Business, 6(1), 59-69. http://doi. org/10.13106/jafeb.2019.vol6.no1.59

Rennie, M., Senkow, D., Rennie, R., \& Wong, J. (2003) Deregulation of the private corporation audit in Canada: justification, lobbying and outcomes. Research in Accounting Regulation, 16, 227-241.

Tauringana, V., \& Clarke, S. (2000). The demand for external auditing: Managerial share ownership, size, gearing and liquidity influences. Managerial Auditing Journal, 15(4), 160168.

Tran, M. D., Khairi, K. F., \& Laili, N. H. (2019). A longitudinal study of audit quality differences among independent auditors. Journal of Economics and Development, 21(2), 234-246.

Watts, R. L., \& Zimmerman, J. L. (1983). Agency Problems, Auditing, and the Theory of the Firm: Some Evidence. Journal of Law and Economics, 26, 613-633.

Zerni, M., Haapamäki, E., Järvinen. T., \& Niemi, L. (2012). Do joint audits improve audit quality? Evidence from voluntary joint audits. European Accounting Review, 21(4), 731-765. 